\title{
Two challenges for the twenty-first century: achieving financial discipline and putting the internationalization process in order
}

\author{
Robert Boyer \\ Director of Studies of the \\ School of Higher Social \\ Science Studies; \\ Director of Research of the \\ National Centre for Scientific \\ Research, Paris.
}

This article takes stock of the situation caused by the Asian financial crisis and analyses the various proposals made for dealing with it so as to avoid its repetition; it is concluded that financial globalization has destabilized the potentially favourable effects of the process of opening up to international trade and productive investment. It notes that while the 1997 financial crisis did not have the deflationary consequences of the 1929 crisis, thanks to the institutional changes made when policy-makers reacted to it, the generalization of export-led growth strategies tends to repeat situations of over-production, further aggravated by the volatility of international capital flows. There is now a feeling that the twenty-first century should mark a dual turning-point: on the one hand, a better balance should be sought between domestic growth and outward-looking policies, and on the other hand -and above all- a number of reforms designed to avoid further great financial crises should be put into effect. A debate is currently under way on the relative merits of various options in this respect: negotiation of a new international system; a Brady Plan for banks; stricter application of prudential regulations; greater transparency of short-term capital movements; the expansion of new options markets, or even the establishment of a Tobin Tax. It would be dangerous to make major structural changes in the productive and social organization of the world's economies solely in response to the pressures of the international financial markets. Lastly, the formation of regional integration areas represents a middle way between internationalization in all directions and a protectionist withdrawal behind national frontiers. At all events, notable changes may be expected compared with the 1990s. 


\section{Introduction}

The 1990s seems to have marked a turning-point in the crisis which began in the late 1960s in the United States and spread from there to the other developed countries through the effects of the oil shocks. The Fordist production model had been gradually losing its effectiveness and was making way for new principles which the Japanese seemed to have discovered and applied with singular efficiency: to such a point that in the 1980s some analysts forecast the "Japanization" of production systems and indeed of the Western economies in general.

The present situation, at the close of the 1990s, is very different, however: the internationalization of trade and production, and even more so the growing force of financial innovations and their spread all over the world, mark a new stage with new types of rules. From now on, growth patterns will be based on the exploration of all aspects of foreign competition and the form of incorporation in international financial networks. In this respect, the United States economy would appear to be leading the way for the other countries, which must adjust in one way or another to this new model governed by finance.

The present study seeks to make a critical analysis of this view of the situation, which is now widely held. It shows that the process of internationalization of trade and production must not be viewed in the same light as the financial globalization process. Financial crises can spread very rapidly from one country to another, but national situations and regulatory systems continue to be very diverse. Thus, the dominant role of financial considerations is above all a feature of the United States and British economies and applies very little to Germany and Japan, to name only two examples of alternatives to a type of capitalism dominated by pure market forces. Moreover, while it is quite true that moderate speculation tends to stabilize the functioning of goods and services markets, excessive accentuation of this process has a potentially destabilizing effect on financial markets. If we accept this interpretation, then it is important to discipline finances. At the same time, however, it must be recognized that not all economies have an export-led growth pattern, so it would not be possible to apply the same political economy precepts everywhere.

The study closes with a comparative analysis of the different solutions proposed for overcoming the potential imbalances marking the current international economy. The ideal solution would be to negotiate a new international financial architecture, but this raises formidable political problems.

\section{II}

\section{Finances for better or for worse}

The last fifteen years have been marked by the deregulation of national financial systems, the proliferation of innovations in terms of new financial instruments, and the de-territorialization of certain markets, to such a point that most national regulatory systems have been significantly changed. Govern-

$\square$ This study was prepared for CEPAL Review on the basis of the updating and expansion of a text originally published in French in Techniques financières et développement, No. 53-54, December 1998. ments decided to engage in this deregulation in the hope of furthering investment, economic growth and employment, without prejudice to the smooth progress of the economic situation (Aglietta, Brender and Coudert, 1990). This trend was observed both in the great industrialized nations and in the emerging economies, where it was reflected in the rapid importation of the most sophisticated financial instruments from Wall Street and the City. It is therefore hardly surprising that the institutions previously governing the growth patterns of most countries have fallen out 
FIGURE 1

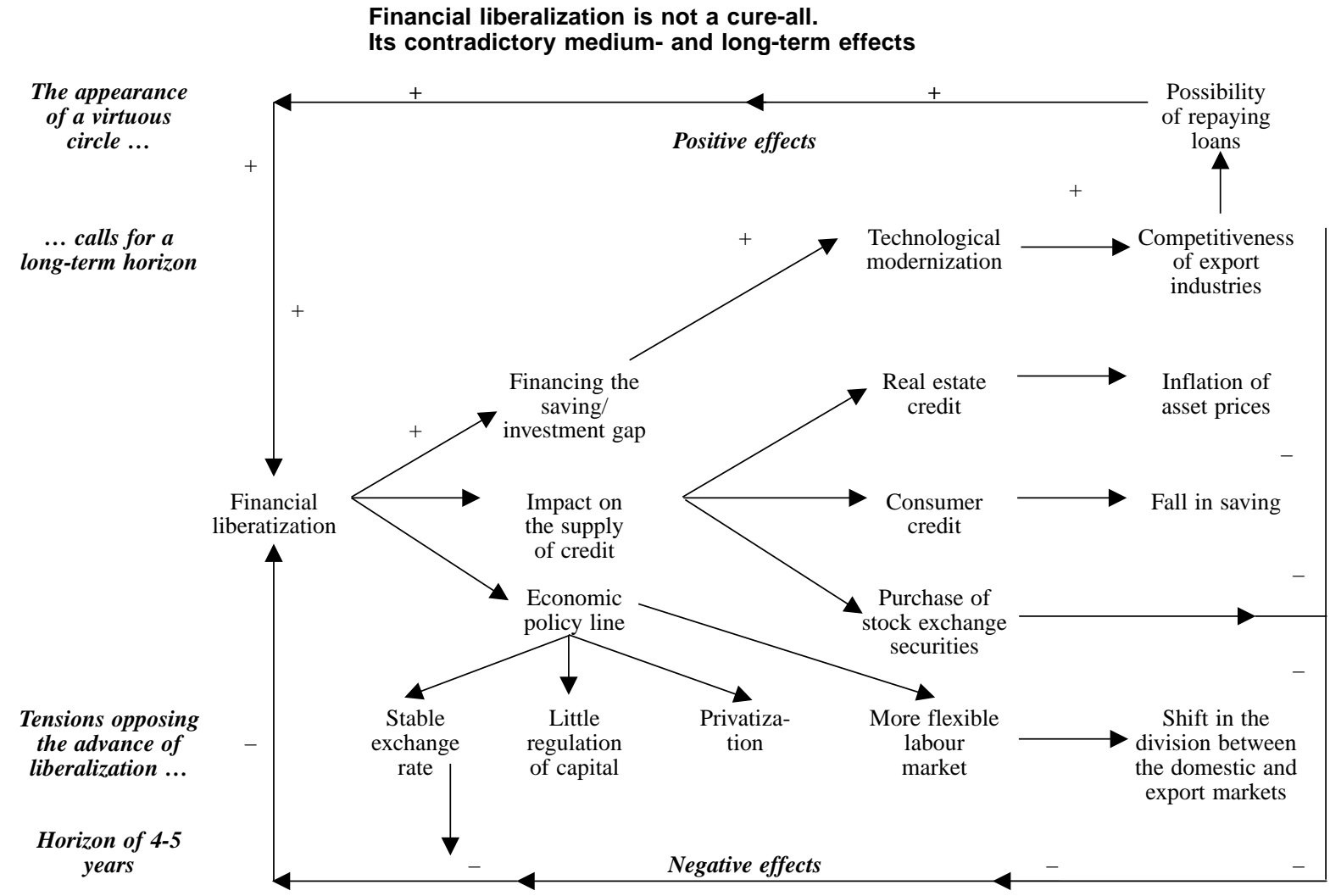

of step with the new financial system resulting from opening up to these innovations.

Looking back, the contradictory effects of this opening up to international finance may be summarized as follows (figure 1):

- On the one hand, when foreign capital inflows take the form of direct investmen they help to form new production capacity incorporating the latest technological advances, because the aim of the transnationals in the 1990s has been to build up a production base in selected countries which will ensure their international competitiveness. This strategy is diametrically opposed to that aimed at import substitution. If the macroeconomic conditions are stable enough and the capital flows continue for a decade or so, it may be expected that the growth in exports will finally make it possible to repay the external indebtedness involved (in this case, private). This trend represents a change from the 1980s, when international loans went to finance public deficits. This is the "virtuous" side of globalization, with international borrowing making it possible to anticipate higher rates of national saving while speeding up growth.
However, there is another and more dubious consequence.

- Thus, on the other hand investment also takes the form of diversification of stock and bond portfolios, giving rise to the concept of an "emerging market". Its effects on the improvement of production efficiency may be seen on the opposite side of the "virtuous circle" referred to above. At first, there is an abundant supply of credit, reflected in a real estate boom, strong expansion of consumer credit, and the purchase of stocks and shares, giving rise to a speculative "bubble" from which none of the reputedly promising countries has escaped, either in Latin America or Asia (Contamin and Lacu, 1998). Asset price inflation, sometimes a fall in the rate of saving, and the shift in production from exports to the domestic market bring on a vicious circle which runs counter to the "virtuous circle" that it was anticipated would prevail when it was decided to introduce financial liberalization. If the exchange rate is kept stable in terms of another reference currency (often the US dollar), this is sufficient to cause inflationary pressures to be reflected in a deterioration in the 
trade balance, which, once it goes beyond a certain level, finally puts the international community on the alert and brings on the withdrawal of short-term capital (UNCTAD, 1998, pp. 59-76).

The drama for Mexico, then Indonesia, Thailand and South Korea, is that this turnaround in the judgement of the financial markets took place before the benefits of technological and industrial modernization had been garnered. Thus, in these countries financial liberalization brought on a series of crises of an unprecedented nature which took finance ministers and central bankers by surprise. Moreover, the events which took place shed doubts on the strategy and adjustment plans of the International Monetary Fund, which are based on a very simple idea: one model, one crisis, one cure for all.

More generally, international finance has made the process of accumulation and consumption ex- tremely flexible in the short and medium term, but with the accompanying risk of increasing the severity of the financial and economic crisis that follows the period of boom and speculation. Over-adjustment -both upward and downward- is a marked feature of the financial markets. While it is well known that all financial bubbles eventually burst, as demonstrated in the notable history of such phenomena by Charles Kindleberger (1978), it is not so normal for them to culminate in a wide-ranging cumulative depression. The only precedent for the crisis of the late 1990s is the Great Depression experienced from 1929 to 1932. However, economic and financial history teaches us that crises follow but do not resemble each other, since the institutional reforms made in order to overcome them give rise to new forms of regulation which can in turn suffer a new kind of structural crisis (Boyer and Saillard (eds.), 1995).

\section{III}

\section{A global financial crisis, but with a variety of national situations}

Does adjustment, which is often dramatically severe, take the same form in all countries? If the hypothesis that globalization is a factor leading to unprecedented coherence of the international system were correct, then such uniformity should actually be observed, subject to a few points of divergence due to the persistence of national institutions still in the course of standardization. In fact, however, globalization represents a new form of interdependence of national economies rather than a force which homogenizes them and blends them in a great melting-pot (Boyer, 1997; Lafay, Freudenberg, Herzog and Ünal-Kesenci, 1999).

This can be seen directly from an analysis of the mechanisms by which the Asian crisis was transmitted (figure 2). Three main mechanisms are involved:

- First, the Asian countries were obliged to accept a structural adjustment plan in order to obtain IMF aid. Such plans, however, were originally prepared for countries suffering from heavy public deficits and lax monetary management, rather than systemic fragility of the banking system. What happened was that, under the influence of a rapid liberal- ization process, there was a failure to introduce the prudential mechanisms and control bodies which proved necessary in the developed countries in order to avoid major financial crises (Williamson and Mahar, 1999; Aglietta, 1995 and 1998). Consequently, the rise in interest rates, the contraction in public expenditure, the pressures to open up the domestic market, and the acquisition of local firms by foreign interests, as well as the questioning of the labour laws protecting wage-earners, are all factors which helped to accentuate the contraction in activity in each country in the first stage. This unfavourable evolution further weakened the banking system and favoured the build-up of fresh bad debts. It is noteworthy that a completely opposite policy was applied in the United States in the fall of 1998: a reduction in the Federal Reserve interest guidelines relieved the pressure on the hedge funds, whose ill-advised speculation could have brought on a systemic crisis.

- Second, most of the newly industrialized countries had obvious excess capacity when the speculative bubble burst (Hochraich, 1999; Godement, 1999). As the adjustment plans sought to reduce do- 


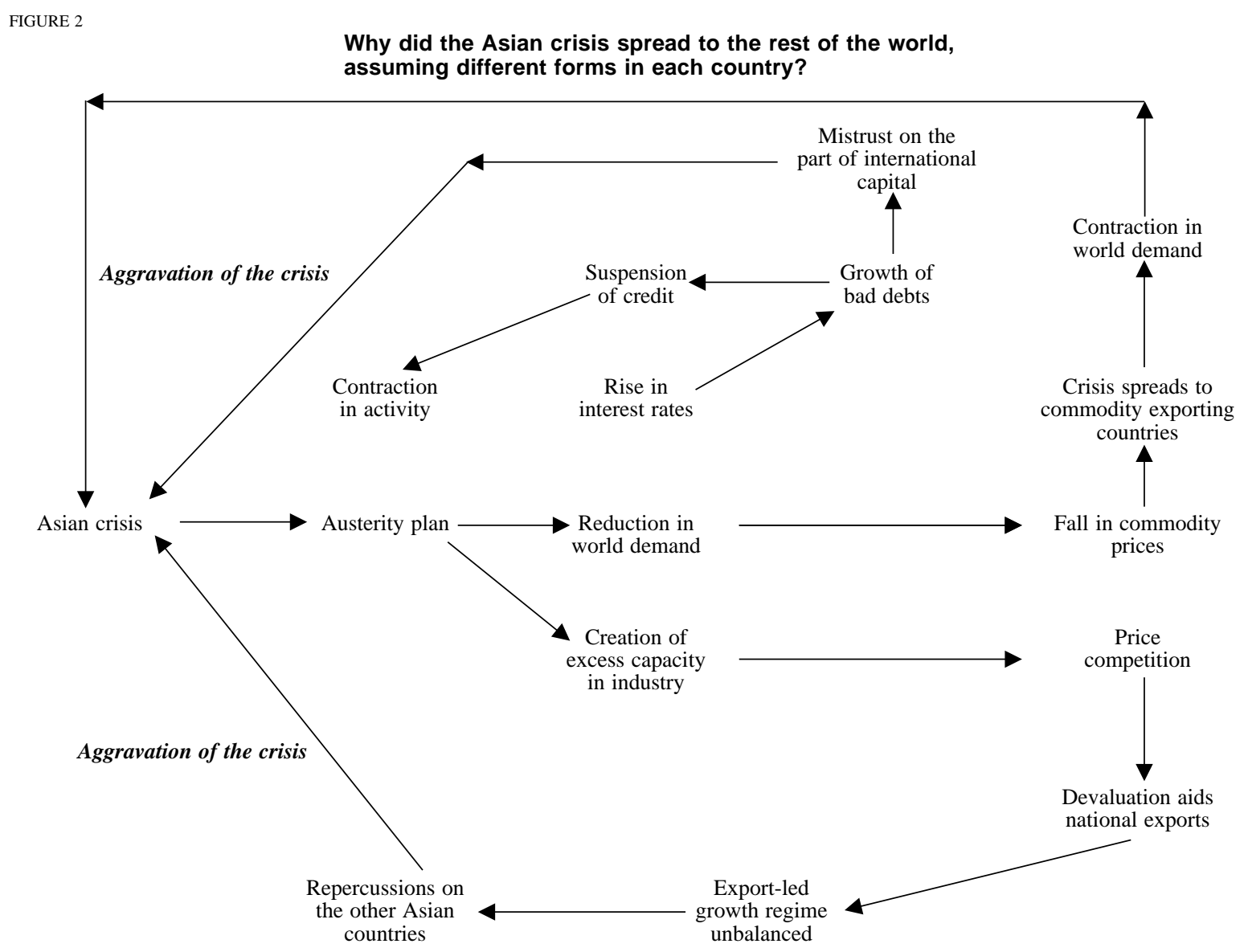

mestic demand, local enterprises turned their efforts towards outside markets. As this was a generalized trend, there was a considerable drop in export prices, which intensified competition with other countries and often led to devaluation of their currencies. This occurred in Southeast Asia, but it was also present in Latin America. The examples of the electronics or motor industries are sufficient to show how the strategy of seeking to export to the world market has led to excess capacity all over the world. It was through this mechanism that the crisis in the Asian countries spread to the most prosperous economies in both North America and Europe. Its effect was favourable as regards inflation control, which is the obsession of the central banks, but its effect on the profits of the great transnationals was more dubious, and it had repercussions in terms of the instability of stock market prices on Wall Street and most of the other markets. After a period of corrections following the August 1998 Russian crisis, the boom in stock prices resumed even more strongly on Wall Street, in the name of a "flight to quality". In view of the reigning uncertainty in Asia, the sluggishness of the Japanese economy and the dismal situation in Europe in the first half of 1999, capital flooded into the United States, starting the speculative bubble all over again.

- Third, the international commodity market is a good barometer for judging the world situation. As Asia had been the most dynamic growth area, the downturn in activity reduced the demand for oil and for primary commodities in general. This is why countries as different as Canada, Norway, Russia and Venezuela were finally affected by the Asian financial crisis, albeit a year later. These developments had repercussions on the expected profits and stock values of the oil companies and those operating on the commodities markets. Even in the commodityproducing countries, the crisis had very special effects: how could what happened in the case of Norway be compared with the effects in Russia, Canada or Venezuela? Forms of regulation remain basically national, but they are subject to shocks which are no 
longer purely domestic but increasingly international (Berger and Dore (eds.), 1995; Hollingsworth and Boyer (eds.), 1997).

So once again we see the diversity of national reactions:

- In Russia, the move towards a finance-based model further destabilized a production system which was already in a very bad way as a result of growing imbalances and opening-up to international trade, even in the case of the most essential goods, such as agricultural products (Sapir, 1996).

- In the United States, the financial crisis only began to make itself felt in October 1998, when the whiplash effect of the summer 1997 financial crisis showed up on the books of the big American corporations. Thanks to the stock market recovery, however, optimism very soon returned and bolstered faith in the emergence of a "New Economy" which would enjoy steady growth and be free from the dangers of both inflation and recession (The Economist, 1999a).

- Japan, for its part, has been experiencing ever since 1991 the difficulty of running a liberalized banking system which is in the midst of a speculative bubble and is hence incapable of solving the problem of bad debts for itself. The evolution of the dollar/yen exchange rate has set the pace at which the Japanese crisis has developed (McKinnon, 1999). Massive budgetary injections and an interest rate close to zero barely served to stave off recession, which finally broke out in the first quarter of 1997.

- In a sense, the Southeast Asian nations have been experiencing a situation of the same type since 1997, although in their case it has been much more violently marked because their form of domestic regulation lacks the stabilizing elements of the Japanese economy (Godement, 1999). Once again, however, it should be noted that there are great contrasts between the way the respective situations evolved in South Korea, Thailand and Indonesia.

- The Latin American countries were also caught in the storm and their policy-makers have been thoroughly disconcerted. As the Minister of Finance of Mexico said in mid-1998: "How is it that Mexico finds itself in a crisis, when the government has followed all the instructions of the international organizations?". The differences between the monetary policies of Argentina and Brazil led to sharp exchange-rate fluctuations which threatened to destabilize MERCOSUR.

- Finally, in Europe the launching of the Euro has made it possible to stabilize exchange rates among the eleven countries participating in this exercise, which fully vindicates the idea of European monetary integration in a sense, but since January 1999 there has been the problem of the international financial markets' appraisal of the viability of this new currency. The difficulties in coordinating national budgetary policies and the conflicts over the strategy of the European Central Bank have naturally heightened the suspicions of the financial community, made wary of risks by their recent experience. The depreciation of the Euro with respect to the dollar between January and August 1999 is as much a result of the differences in situations and in monetary policies between Europe and America as of the difficulty of giving birth to a new currency in a context of globalized financial markets (Boyer, 1999a).

\section{IV}

\section{The trend towards a finance-based model is still very uneven between countries}

The persistence of marked differences between the paths followed by individual countries suggests that globalization is far from having taken possession of all countries and hence transforming all their domestic economic institutions. This disparity between transnationalizing financial innovations and national institutions may be interpreted in two different ways, however.

- It may be considered, for example, that the magnitude of the crisis in the Asian countries is due to their delay in adopting all the rules of a fully developed financial economy, so that financial open- 
TABLE 1

The North American economy is based on finance to an exceptionally high degree

\begin{tabular}{|c|c|c|c|c|c|c|}
\hline & $\begin{array}{l}\text { United } \\
\text { States }\end{array}$ & $\begin{array}{c}\text { Great } \\
\text { Britain }\end{array}$ & Canada & Japan & Germany & France \\
\hline 1. Propensity to consume, 1996 & 0.95 & 0.926 & 0.956 & 0.869 & 0.884 & 0.908 \\
\hline $\begin{array}{l}\text { 2. Stock holdings/disposable } \\
\text { income, } 1997(\%)\end{array}$ & 145 & 75 & 95 & 30 & 25 & 20 \\
\hline 3. Capital gains/disposable income $(\%)$ & 35.5 & 15 & 11 & -7 & 7 & 5 \\
\hline $\begin{array}{l}\text { 4. Share of stocks and bonds in } \\
\text { financial assets of households }\end{array}$ & 28.4 & 52.4 & $\ldots$ & 25.3 & 21.3 & 14.5 \\
\hline 5. Money market rate & 5.34 & 7.38 & 5.20 & 0.32 & 3.5 & 3.46 \\
\hline 6. Yield on bonds & 6.51 & 5.59 & 7.30 & 1.06 & 3.97 & 4.23 \\
\hline 7. Reference yield (\%) & $12-16$ & $12-16$ & $12-16$ & 5 & $6-7$ & 9 \\
\hline
\end{tabular}

Source: Line 1: Keizai Koho Center (1998, p. 97). Lines 2 and 3: The Economist (1998, p. 129). Line 4: Japan Almanac (1998). Line 5: The Economist (1998, p. 129).

ness has not been accompanied by the corresponding modernization of risk management facilities (Williamson and Mahar, 1999). Consequently, governments should press on with the importation of the kind of rules and control bodies which govern the financial systems of the United States or Great Britain: traditionally the countries which have gone furthest in innovations and risk management. This is clearly the question for Japan. It is also clear, however, that the other domestic institutions should be reformed accordingly too, since the maintenance of the highest and stablest yields possible, as demanded by pension funds, for example, is not generally compatible with the codification of wage relations or the style of management practiced by the State. This is why in South Korea, for example, the question of more flexible labour regulations has come up once again after the 1997 crisis.

- In contrast, it may be considered that the present financial crisis is simply another episode, coming after many others (Kindleberger, 1978), in which speculation has tried to break loose from the economic and social constraints which previously affected it, but in which a crisis has very soon occurred whose severity shows the non-viability of a system governed solely by finance: a subject dear to the heart of John Maynard Keynes (1935), and also of Karl Polanyi (1946). According to this second interpretation, it is necessary to bring back some discipline into financial innovation in order to make it comply with the need to stabilize the international economy and ensure steady accumulation of productive capital at the national level (Orléan, 1998 and
1999). In this respect, is it not noteworthy that the economies where financial liberalization has been carried out in a prudent manner (Germany, India) or where productive capital has been made welcome but not speculative funds (Chile before 1998) have registered a much more controlled evolution, without major crises, in spite of the world economic upsets around them?

Indeed, the fact is that by no means all countries are on the verge of adopting a new system of accumulation governed entirely by finance (table 1). Only the so-called Anglo-Saxon countries, headed by the United States, are serious candidates for such a system, for the proportion of their wealth held in the form of stocks and shares is high with respect to their disposable income and seems to play some part in a particularly high propensity to consume which, moreover, increases still further as the financial investments of American households develop. In September 1998, the rate of saving in the United States became negative $(-0.2 \%)$ because households financed their consumption by resorting to credit: a situation without precedent since 1959. Furthermore, the Stock Exchange is an essential means of capital allocation and control over the way firms are run, through, for example, the pursuit of much higher yields than in Europe or Asia. In contrast, Germany is very far from having these characteristics, which no doubt explains the different types of evolution observed on the opposite sides of the Atlantic.

The other European countries, as well as Japan, are also a long way from adopting the finance-based economic model, and this is not necessarily a handi- 
TABLE 2

North American capitalism is not so

superior in terms of efficiency

\begin{tabular}{|c|c|c|c|c|c|c|c|c|c|c|}
\hline & \multicolumn{2}{|c|}{$\begin{array}{l}\text { Efficiency of } \\
\text { companies }\end{array}$} & \multicolumn{3}{|c|}{$\begin{array}{l}\text { Access to } \\
\text { employment and } \\
\text { hours worked }\end{array}$} & \multicolumn{2}{|c|}{$\begin{array}{l}\text { Distribution of } \\
\text { fruits of growth }\end{array}$} & \multicolumn{3}{|c|}{$\begin{array}{l}\text { Social justice. } \\
\text { Ratio of male workers' } \\
\text { wages, deciles } 9 \text { and } 1\end{array}$} \\
\hline & $\begin{array}{l}\text { Profit- } \\
\text { ability, } \\
1997 \\
(\%)\end{array}$ & $\begin{array}{l}\text { Growth rate } \\
\text { of manufac- } \\
\text { turing } \\
\text { product- } \\
\text { ivity, } \\
1990-1997 \\
(\%)\end{array}$ & $\begin{array}{c}\text { Hours } \\
\text { worked } \\
\text { per } \\
\text { year, } \\
1996\end{array}$ & $\begin{array}{c}\text { Growth } \\
\text { rate of } \\
\text { employ- } \\
\text { ment, } \\
1990- \\
1998 \\
(\%)\end{array}$ & $\begin{array}{l}\text { Unem- } \\
\text { ployment } \\
\text { rate } \\
\text { (August } \\
1998 \text { ) }\end{array}$ & $\begin{array}{c}\text { Growt } \\
\text { rate of } \\
\text { consump- } \\
\text { tion, } \\
1990- \\
1997 \\
(\%)\end{array}$ & $\begin{array}{c}\text { Size of } \\
\text { public } \\
\text { and } \\
\text { social } \\
\text { transfers/ } \\
\text { GNP } \\
(\%)\end{array}$ & 1979 & 1995 & $\begin{array}{c}\text { Annual } \\
\text { rate } \\
\text { of } \\
\text { change } \\
(\%)\end{array}$ \\
\hline \multicolumn{11}{|c|}{$\begin{array}{l}\text { Countries which } \\
\text { adopted liberalism }\end{array}$} \\
\hline United States & $\ldots$ & 3.2 & 1986 & 1.3 & 4.6 & 2.4 & 32.0 & 3.18 & 4.35 & +2.7 \\
\hline Great Britain & 10.4 & 3.9 & 1926 & 0 & 6.3 & 1.8 & 39.7 & 2.45 & 3.31 & +2.0 \\
\hline \multicolumn{11}{|c|}{$\begin{array}{l}\text { Countries with a } \\
\text { strong public tradition }\end{array}$} \\
\hline Germany & 14.5 & 2.7 & 1517 & -0.6 & 10.7 & 1.8 & 47.7 & 2.38 & 2.25 & -1.3 \\
\hline France & 15.9 & 2.8 & 1679 & 0.1 & 11.8 & 1.2 & 54.1 & 3.39 & 3.43 & +0.2 \\
\hline \multicolumn{11}{|c|}{$\begin{array}{l}\text { Meso-corporativist } \\
\text { countries }\end{array}$} \\
\hline Japan & $\begin{array}{c}12.8 \\
(1)\end{array}$ & $\begin{array}{l}2.2 \\
(2)\end{array}$ & $\begin{array}{r}1993 \\
(3)\end{array}$ & $\begin{array}{l}0.6 \\
(4)\end{array}$ & $\begin{array}{l}4.3 \\
(5)\end{array}$ & $\begin{array}{l}2.0 \\
(6)\end{array}$ & $\begin{array}{c}35.2 \\
(7)\end{array}$ & $\begin{array}{r}2.59 \\
(8)\end{array}$ & $\begin{array}{r}2.77 \\
(9)\end{array}$ & $\begin{array}{l}+1.2 \\
(10)\end{array}$ \\
\hline
\end{tabular}

Source: Columns 1, 2, 4, 5, 6 and 7: OECD, 1998 (calculations made on the basis of the statistical annex). Column 3: Japan Almanac, 1999, p, 107. Columns 8, 9 and 10: Richard Freeman, 1998, p. 44.

cap, as we can see by comparing some major performance indicators: in these countries, productivity grows at roughly the same pace as in the United States or Great Britain, and at the end of the 1990s their firms are making perfectly satisfactory profits, but income distribution is much fairer than in the highly finance-based countries (Boyer, 1999b).

It is by no means obvious that European and Japanese policy-makers should force the pace of financial liberalization in order to meet the demands of globalization. This advice is often proffered to Japan, which is recommended to import most of America's institutions if the government intends to try to overcome the serious crisis of the 1990s (Dornbush, 1998), but in fact it would appear to be easier, wiser and finally just as effective simply to make marginal reforms in the institutions inherited from the time of rapid growth. To be sure, the persistence and magnitude of unemployment in Europe and its rapid increase in Japan naturally shed some doubts on the viability of the institutions governing labour relations and the labour market, but the cost/advantage balance is not weighed clearly in favour of an American-type model (table 2). As Richard Freeman (1998) noted, contrary to general belief, the United States has not by any means reached a kind of economic nirvana, except in the case of the richest households, and it would not be advisable for Europe -even if it were possible- to imitate the American model in all its details. The example of Britain points in the same direction: adoption of a finance-based model has increased inequality without having much effect on firms' efficiency (Froud, Haslam, Johal, Leaver, Williams and Williams, 1998). 


\section{V}

\section{The great financial crises follow but do not resemble each other}

This interpretation has important implications for understanding the crisis that broke out in 1997, spread to the rest of the world, and got worse in the fall of 1998. The spectre of a return to the catastrophic chains of events observed between 1929 and 1932 once again haunts the financial community and the international organizations. A step by step comparison, enlightened by regulation theory (Aglietta, 1976; Boyer and Saillard (eds.), 1995), tends to tone down these conclusions, however (table 3).

At a certain level of abstraction, there is no shortage of analogies between 1929 and 1998 .

- For a start, a series of speculative bubbles ended up by bursting, first in Japan in 1990, then in the Southeast Asian countries in 1997, and finally in the United States in the fall of 1998. It should be noted, however, that the order of the crises was different from that of the 1930s: at that time it was the United States economy which was hit first by the outbreak of the financial crisis which then spread to the other developed economies and finally to the "periphery". In the 1990s, the opposite took place as a direct result of the booms on the emerging markets, which thus brought the instability of the centre to the periphery. However, the more highly developed and firmly established prudential control arrangements in North America slowed down the spread of the crisis associated with the bursting of the Asian financial bubble. Paradoxically, these uneven degrees of financial maturity sent financial flows back towards Wall Street as from late 1998/early 1999. However, the weakening yield/risk ratio and the fact that the financial yield tends to be higher than the economic yield proper shed doubts on the long-term viability of the path followed by the United States economy since 1991 (Artus and Debonneuil, 1999).

- Secondly, the accumulation regime displays certain similarities. In many countries, it is marked by a profit rate which is considerably higher than in the 1980s, but with insufficient demand to keep up such a level of profitability in the long term. It is therefore a crisis of realization rather than of valuation which looms on the horizon. The United States is an exception to this, but in 1997 most of the other OECD countries were in a situation rather reminiscent of that prevailing when the 1929 crisis broke out in the United States. The effects of the existence of excess capacity were naturally heightened by the slump in demand from the Asian countries. So far, the United States has been the "buyer of last resort", but a conjunctural turnaround in that country would assuredly reveal the magnitude of the imbalances which have built up at the world level (Brenner, 1998). A second paradox is that most of the developed countries still have a growth regime driven by domestic consumption (Bowles and Boyer, 1995), whereas almost all governments base their policy decisions on the hypothesis that growth is conditioned by profit and competitiveness. This error of diagnosis was already present in the 1930s.

- The third point of similarity is that the international financial system presses in favour of downward readjustments, which obliges countries with an external-sector deficit to adopt austerity plans, whereas the countries with a surplus have no incentive (or are unable, like Japan) to reactivate their economies, since the financial fragility of the banks leads to a generalized "wait and see" attitude with regard to investment and consumption. Moreover, financial adjustments can be brutal and rapid, whereas adjustments in economic activity and specialization continue to be much slower. This great lesson from the General Theory remains fully valid in these times of electronic money and globalized finance. In 1929, too, the speed with which the financial crisis spread was a decisive factor in the size of the depression and the contraction in economic activity.

- Lastly, even at a time which is supposed to be marked by globalization there is still no supranational system of regulation to ensure the viability of a variety of national growth regimes governed by finance. Although it is quite true that there are international organizations such as the IMF and the Bank for International Settlements which are responsible for preventing financial crises, it is equally true that they do not have the financial or political resources to in- 
TABLE 3

From a financial crisis to a structural crisis:

a comparison of 1929 with 1998

\begin{tabular}{lcl}
\hline 1929 & 1998 \\
\hline
\end{tabular}

Nature of system of accumulation

United States

Other industrialized countries

Non-industrialized countries

Ranking of institutional forms

Sources of crisis

United States

Other industrialized countries (such as France, for example)

Recently industrialized countries
Intensive, without mass consumption

Intensive, without mass consumption

Dynamism of finance

Wave of concentration

Largely competitive wage relations State not supposed to be interventionist

Multi-polar international order

Excessively high profits compared with effective demand

Speculation in financial markets

Excessively high profits compared with effective demand

Fall in commodity prices Rapid shifts of capital

Optimism of agents: "A New Era"

Over-valuation of stock markets

More erratic evolution of stock prices

Federal Reserve Bank reluctant to intervene

Growth paralysed by stock market crisis
Extensive, with differentiation of consumption

Moderately intensive, governed by competitiveness

Dependent on foreign capital and exports

Globalized finance controls companies and governments

Wave of concentration in response to demands of financial markets

Erosion of wage earners' bargaining power Indebtedness of State limits autonomy of economic policy

United States has leadership power, but the world is of a multi-polar nature

Speculation feeds consumption and conceals the imbalance in the accumulation system Profits demanded by finance are not compatible with the long-term profit rate

Imbalances in the accumulation system are transmitted to external markets (excess capacity; pursuit of trade surpluses)

Financial crises are transmitted to the domestic economy

Discrepancy between time-scale of finance (attraction of capital) and time-scale of production (generation of a trade surplus) IMF adjustment plans aggravate the imbalances

Fall in commodity prices Instability of capital movements

New economy with constant growth Over-valuation of stock markets Great instability of stock prices Federal Reserve Bank conscious of danger of a systemic collapse

Dynamic growth continues, but profits are under stress

Deflation of assets since 1992, general deflation since 1997

Contraction in credit due to bad debts and uncertainty 
tervene when there is a "domino effect" serial collapse that results in a major crisis that could exhaust their resources and means of intervention. The recapitalization of the IMF agreed at the end of October 1998 (Camdessus, 1998) and the guidelines given by the Group of Seven (G-7) bear witness to the awareness of the danger that financial instability represents for the cohesion of the world system, but this does not mean that the arms available to the international organizations are in keeping with the dangers involved in a possible recurrence of speculation. Thus, for example, the fact that the IMF granted Brazil a line of credit for US\$ 41 billion (IMF, 1998a) to ward off speculative movements still did not prevent the brutal devaluation of the Real after the Brazilian Presidential elections.

Thus, although there are some common features between 1929 and 1998, closer analysis of the forms of regulation and strategies adopted by governments reveals some notable differences.

- In the old industrialized economies, the wage-earning society continues to set the form of regulation, through a closely-knit network of interdependent institutions. The relative inertia of adjustments in employment, hiring and the collective negotiation of wages, the existence of a minimum wage, the breadth and diversity of coverage of social security and the existence of unemployment insurance are all typical features of a form of labour relations which in many countries -especially in Europeprevents a slump in consumption and hence in economic activity. This is one of the hidden stabilizers which prevented the repetition after the first oil shock of the catastrophic episodes that took place between the wars. On the other hand, however, this institutional stability can prevent changes in the form of regulation and the establishment of a development regime more in keeping with both domestic and international constraints.

- A second difference from the 1930 s is that previously the countries of the periphery were mainly suppliers of raw materials and semi-processed goods for the industrialized economies, whereas now much of the production of the Southeast Asian countries and some of the Latin American countries takes the form of manufactures which compete with the products of the OECD countries. For this reason, the excess of manufacturing capacity is no longer observed only in the United States or Europe, but at the world level, in the newly industrialized countries, including China, which has made rapid progress since 1978 in its process of industrialization and entry into the world market. The crisis of excess production is therefore much more difficult to handle now, since it affects different countries: it is a potential source of international economic conflicts, and this makes it all the harder to find a positive solution for the present difficulties. We are thus now involved in a dangerous and potentially zero-sum game instead of the positive-sum game of the past.

The experience of the catastrophic chains of events of the 1930s (financial crisis -competitive devaluation- withdrawal into protectionism -rising nationalism- world conflict) continues to exert a powerful influence on the political and economic leaders of the 1990s, even though few of them actually lived through these episodes. Thus, in mid-1998 the President of the United States, the President of the Federal Reserve Board, the top executives of the World Bank and the IMF, and the Finance Ministers of the Group of Seven all proclaimed their intention of preventing the financial crisis from degenerating into an economic depression. This is why the great financial crises follow but do not necessarily resemble each other.

This is the central message of regulation theory: the great crises follow one another, but never in an identical form, because it is typical of capitalism that it evolves in a spiral, never passing twice through the same configuration (Boyer, 1999b). Such an economic system favours ongoing innovation, and crises and conflicts give rise to the readjustment of institutional forms, which are thus marked by a strong historical element and notable irreversibility. Each structural crisis tends to be new and original in terms of the interaction of its causes and transmission mechanisms. This is a challenge to the current neoclassical theories, which claim instead that the determinants of macroeconomic balance remain unchanged in space and time. 


\section{VI}

\section{Disciplining world finance: a New Deal for the twenty-first century?}

All is not for the best in the best of worlds: since the Asian crisis broke out in 1997 belief in the self-balancing nature of the financial market has been severely shaken and the Russian crisis in 1998 led to further questioning of this eminently optimistic conception. In this respect, it is significant that the financial press has now begun to talk about a new "New Deal" centered on the debt problem (Business Week, 1998, p. 60). This proposal is interesting from more than one point of view.

Firstly, it comes from the big industrial corporations, which have noted that the expansion of globalized finance, which was supposed to facilitate their operations and raise their profitability, may in fact prove harmful to them, because it gives rise to instability on product markets and fosters phases of contraction of bank credits which affect both consumption and investment. This is a message which had already been highlighted by the first studies on speculation: while a little speculation may stabilize product markets, its generalized spread to finance brings major instability (Kaldor, 1940). In the face of growing uncertainty, imitative forms of behaviour become general, thus tending to increase the likelihood and magnitude of financial bubbles (Aglietta and Orléan, eds., 1998). Last but not least, financial globalization creates great uncertainty about the evolution of exchange rates, interest rates, and even the very direction of national economic policies and hence also of growth. The way financial liberalization and globalization evolve brings to mind the image of the sorcerer's apprentice, overwhelmed by his own creations.

Secondly, the choice of the term "New Deal" is enlightening because it contrasts with the meaning this term had for the Unite States after the economic collapse in 1929. At that time, financial and banking activity was strongly regulated once again: for example, the law prohibited deposit banks from carrying on activities with stocks and securities, precisely in order to avoid the sources of systemic fragility which manifested themselves once again in the 1990s. The new situation was therefore related mainly to the status of wage-earners, who were granted a number of rights that went against pure market logic: minimum wage, right to retirement, right to education, right to share in the fruits of economic activity, etc. In the 1990s, in contrast, the journalists of Business Week were advocating the equivalent of a Brady Plan. It may be recalled that this Plan had converted Latin American public debt into securities tradeable on financial markets. In 1998 this proposal was expanded to cover the absorption of unpaid private debts owed to the banks. This new "New Deal" thus referred to an institutional arrangement between bank capital and financial capital, which is clear proof of the place now occupied by finance, both in the United States and in the newly industrialized countries. Incidentally, this plan confirms that errors of management are not restricted to governments or to Latin America but also affect banks and private firms and can even affect most Asian countries, though not all, as shown by the example of Taiwan. A few years ago, these countries were still considered as possessing special virtues (World Bank, 1993), and there was a danger of underestimating the structural weaknesses which had nevertheless been present for a long time in such economies as South Korea or Indonesia (Hochraich, 1999; Godement, 1999).

However, these proposals completely overlook the fact that unless there are new national commitments to stabilize domestic demand the economies hardest hit by the financial crisis will not be able to recover their growth. It is important not to try to solve the problem of over-production by exaggerated reductions in export prices but, instead, to look for ways of returning to the growth path through more buoyant domestic demand and establishment of the infrastructure needed for long-term development. There are great needs in Asia, Latin America and above all Russia, where a third of the population is below the poverty line and the number of people in this situation has grown steadily since 1995. The main criticism that can be levelled at the IMF's plans 
for the Asian countries is indeed that they aggravated the contraction of domestic demand instead of stimulating it, in contrast with the economic policy applied by the OECD countries (lower short- and long-term interest rates, increased public expenditure). Furthermore, there is an increasingly widespread conviction that all national economies should base their economic growth on improvements in their competitiveness: that is to say, they should adopt an export-led model. This error would be all the more harmful because it would assume that the United States would play the part of "consumer of last resort".

\section{VII}

\section{The paths open for the future: multiple policy options}

If we take the proposal for a new "New Deal" literally, then, it is essential that governments should look for a broader range of options and adopt a strategy better adapted to the diversity of political coalitions, the particular needs of specialization, and the need for better international linkages. In the final analysis, there will be as many strategies as there are types of trajectories of the societies in question, whose forms of regulation will continue to be very different (Amable, Barré and Boyer, 1997). It is encouraging that there has been an increase in the number and variety of proposals since mid-1998 (figure 3 ). On the other hand, it is regrettable that the unexpected dynamism of the United States economy up to mid-1999, the halt in the recession in Japan and the lull in the problems of Europe have tended to put off the implementation of these proposals.

The first strategy, proposed by British Prime Minister Tony Blair, is to negotiate a new international system. This proposal is supported by the Keynesian-inspired economists and experts who propose a new international architecture (IMF, 1998a; CAE, 1999a and b). What should have been a priority item on the policy-makers' agenda ever since 1971, after the two oil shocks, and even more so after the financial liberalization, has finally become a current issue. But for this to happen we had to witness the destructive effects of speculation in the 1990s, although the December 1987 stock market crisis should have sounded an alarm for both analysts and policy-makers. The difficulty now lies in the content of the reforms, since the different countries have different, if not downright contradictory interests, depending on whether they are debtors or creditors, whether they are responsible for a significant part of international financial intermediation or not, and so forth. The precedent of Bretton Woods suggests that political and geopolitical factors predominate, since in spite of the talents of John Maynard Keynes, the United States plan was eventually imposed. This seems to ensure that the initiatives of Washington and New York, which are at the heart of the financial globalization process, will be crowned with success, and both the economic benefit of the United States and its diplomatic leadership have been strengthened over the last decade.

Containing the risk of contagion with bad debts is a second option. In a sense, this would appear to be easier to achieve, because it involves less political opposition. The idea of a Brady Plan, taken up again by Business Week, is logical up to a point because it aims to make the banks and financial institutions which have accumulated these bad debts pay part of the cost of the adjustment, thus relieving the burden on the public finances and on taxpayers, who generally have little capacity to privatize benefits and socialize losses. There could also be a move towards concentration, through mergers of big banking or financial establishments at the international level. This trend has already been observed in the United States and Japan, but it could spread across national frontiers and thus give rise to new international alliances. Finally, the idea of strengthening the funds available to the IMF for solving or forestalling international financial crises (Camdessus, 1998) now appears to be a priority, in spite of parliamentary opposition to greater public expenditure, in view of the serious risk of a systemic financial crisis perceived in the late 1990s. Furthermore, the independent Central Banks must learn to operate in a more interdependent man- 
FIGURE 3

\section{How to surmount the financial globalization crisis:} an overview of the strategies open to governments

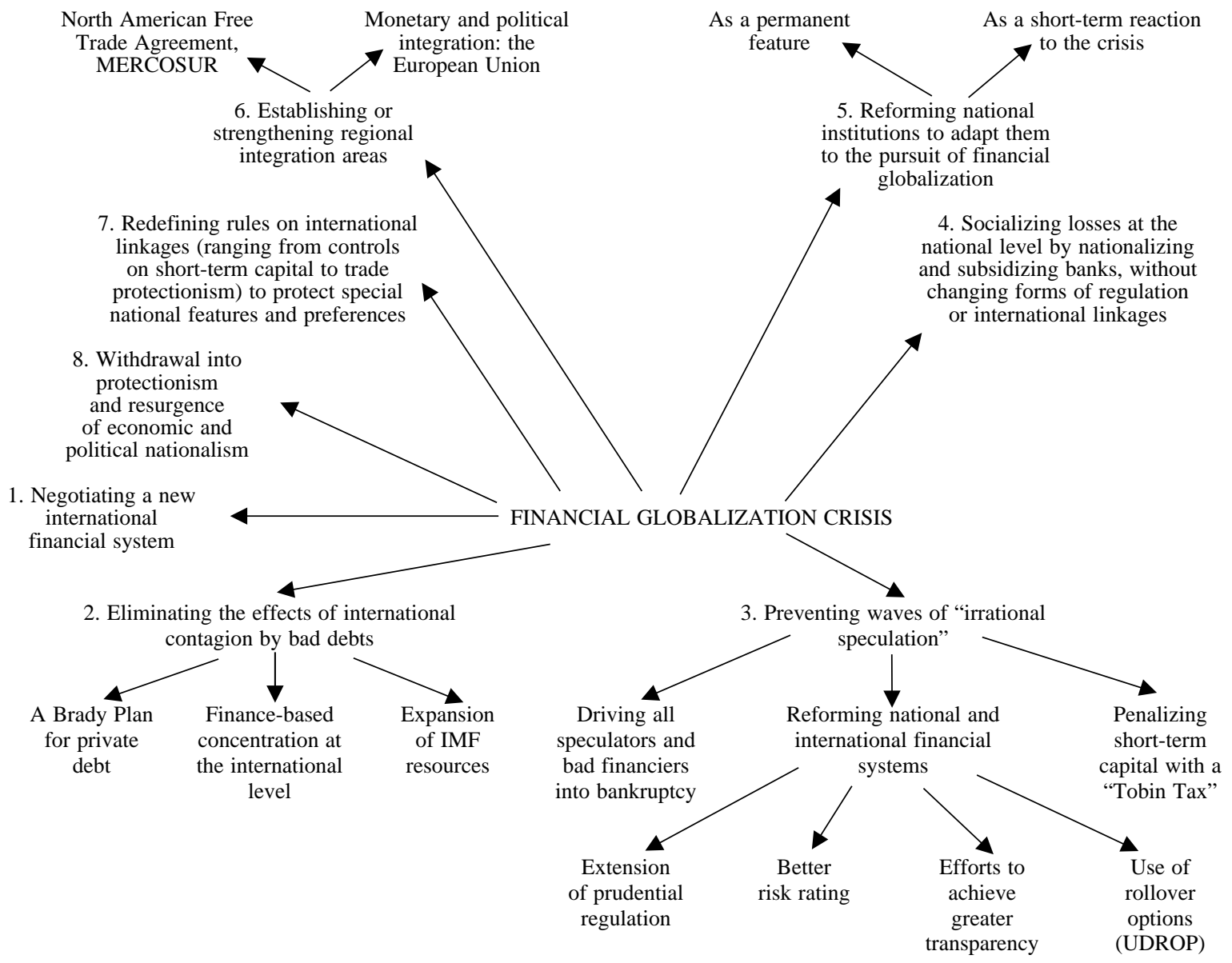

ner now that financial globalization has increased the risk of instability (Aglietta and Cartelier, 1998).

Preventing future outbreaks of "irrational speculation" (to use the term employed in 1997 by Alan Greenspan when he was trying to stop Wall Street from getting out of control) is a third strategy whose actual form will depend on various possible lines of action which will ultimately prove very different from each other.

The conservative tradition, basing itself on the theory of moral hazard, recommends bankrupting all speculators who are not able to pay their debts and all bankers who have made too many mistakes. The idea is that if they are sure that in future the public authorities will not come to their rescue, financiers will opt for more cautious evaluation of risks, so that the next speculative bubble will be more moderate or will actually be nipped in the bud. This is quite reasonable, but in the meantime what is to be done if the bad debts are so numerous that they endanger the credibility of the whole financial system?

A more moderate solution is to strengthen the prudential supervision regulations by, for example, extending them to hedge funds or even raising the amount of deposit insurance (BIS, 1998). Experience shows, however, that such measures have not been totally effective in recent years, for the nature of risk shifts in line with the systems of protection set up, 
which in the opinion of some experts explains the seriousness of the Asian financial crisis: speculators are very familiar with the previous IMF interventions and adjust their strategies accordingly. Insurance simply shifts, and may even increase, the risk.

It has therefore been proposed that the risk appraisal procedures for banks and other financial institutions should also be reformed. In this case, the public authorities would be responsible for ensuring the certification and implementation of these procedures. There can be no doubt that there has been an improvement in the soundness of financial systems. Nevertheless, the example of the near-failure of Long Term Capital Management (a United States hedge fund) shows that even the most expert advice on the calculation of option values, provided by two Nobel Prize winners who won that distinction precisely for their work on option value theory, is no guarantee of success (Croff, 1999), for when market opportunities are exploited to the full their global properties change or may be affected by unprecedented changes (Rohatyn, 1999; Artus and Debonneuil, 1999).

A more ambitious and much more radical proposal was put forward in 1978 by James Tobin: taxing short-term capital at a rate which is very modest but has a cumulative effect in penalizing speculation and thus making long-term productive investment attractive again. The situation existing in the 1990s has given rise to renewed debates about such a reform (Haq, Kaul and Grunberg, eds., 1996). The traditional objection to this proposal is that there will always be tax havens to which capital will flow, even if the big industrialized countries were to agree on the simultaneous, coordinated application of such a tax. On the other hand, the example of Chile shows how a country can unilaterally penalize speculative capital or even prevent it from entering the country at all: it is quite true that international capital flows turn away from the country in the short term, but as soon as it registers strong growth with high profit rates productive capital returns. Theoretical models indicate that it is beneficial for a country to slow down short-term capital movements, because the short-term losses are amply offset by the medium- and long-term gains. Indeed, the greater stability of the capital formation process, the generation of learning effects and the reduction of uncertainty lead to more even and ultimately stronger growth (Eliasson, 1984).

At a time which is totally dominated by the financial markets' perception of the credibility of eco- nomic policies, many analysts feel that it is more reasonable to aim for transparency of capital movements (Davanne, 1998). By pooling real-time statistical data, the multinational authorities, aided by governments, could make early diagnoses of impending liquidity crises and prevent them from turning into systemic crises, the idea being that rational agents would take these data fully into account and eschew the imitative forms of behaviour which precipitate financial crises. Once again, however, financial history sheds some doubt on the sovereign nature of this remedy (Kindleberger, 1978): in the past, the sophistication of the information available to the actors on financial markets has not prevented the repetition of severe financial crises. Indeed, modern financial market theory shows that there is nothing irrational about speculation and that rational bubbles can form even under the transparency hypothesis (Orléan, 1999). A measure of this type is not useless -far from it- but it is not of itself sufficient.

Other experts have proposed that liquidity crises should be dealt with through the creation of options markets capable of preventing a transitory and accidental liquidity problem from turning first into a financial crisis and then a major macroeconomic crisis. The idea is that all debts denominated in foreign currency should be accompanied by an option, usable at the borrower's discretion, to postpone the debt's maturity by three to six months, subject to payment of a penalty. The is the "Universal Debt Rollover Option with a Penalty (UDROP)" proposed by Buiter and Sibert (1999). The beauty of such a measure is that it would not call for any public funds, unlike interventions by the IMF or national Central Banks, and it would heal the ills of the market through the extension of market mechanisms: a tendency which would fit in very well with the ideas of the 1990s and after. Unfortunately, as long as liquidity crises spread and get worse under the impact of imitative behaviour, major financial imbalances will continue to require public intervention, so that this measure would have to fit in with the variety of instruments described earlier but could not take their place.

Socializing losses through the fiscal budget is the fourth option for dealing with the bad debt buildup inherited from the 1990s. The argument put forward in favour of this approach is that, over a certain threshold, private agents' errors of management 
and foresight can compromise the viability of the payments system as a whole, and with it the cohesion of the domestic economy. There is nothing wrong, then, with carrying out an act of national solidarity, through the use of tax resources, to restore the dynamics of credit, investment and consumption. The Japanese example shows that these measures are highly unpopular, so that they can only be adopted when the government is very strong or the crisis is so devastating that it dispels the average citizen's reluctance to compensate some rich speculators for the mistakes they have made. Nevertheless, most governments, be they conservative or social democratic, American or Scandinavian, have had to resort to this method in order to avoid a possible collapse of the entire banking and financial system. Even so, it is reasonable to advance the moral hazard argument when this is the only measure taken by governments: when they are sure that they will not be allowed to go bankrupt, banks and financiers will gaily indulge once again in the delights of speculative bubbles.

A fifth solution would be to reorganize national institutions in order to adapt them to the needs of internationalized finance. This is a solution proposed by analysts who believe (even now!) that globalization is an irreversible phenomenon and that once the period of disturbances comes to an end the emerging markets will begin to grow again even faster than before. Consequently, they say, it is necessary right now to reform the fiscal structure, improve the quality of public infrastructure, and eliminate all the "rigidities" from industrial relations by promoting everywhere and at all times a rapid adjustment to the unforeseeable situations generated by the generalized spread of the "casino games" displayed by modern finance in recent times. In fact, there is nothing irreversible about globalization (Boyer, 1997a and b), and a change of course of the internationalization process to take account of the limits observed in the 1990s is quite probable (Epstein, 1996 and Helleiner, 1996). Moreover, it is worth recalling the argument put forward by Karl Polanyi (1946): societies run to ruin if mercantile relations permeate such a central institution as the currency and if they seek to completely dominate labour and the logic of the anthropomorphic reproduction of generations (Aglietta and Orléan (eds.), 1998). For its part, the General Theory long ago showed that it was futile to try to return to full employment by making wages as flexible as stock market prices. Finally, and above all, regulationist studies suggest that it was the firmness of the original commitment between capital and labour and the strict circumscription of finance which made possible such rapid and even growth after the second world war (Boyer, 1999b). Despite appearances and the relative weakness of the organizations for the defence of wages, the negotiation of a veritable "New Deal" between employers and workers must be high on the agenda, not only because it fits in with the needs of short-term adjustment but also because it must be the ongoing characteristic of a form of development which would also take account of the dynamics of social needs in each society and not just export competitiveness.

Another option open to national leaders is to set up regional integration areas. Thus, it is seen that trade does tend to increase in the three poles of the triad: this is very clear in the case of Europe and is also to be observed in the case of North America with NAFTA (a later and less vigorous movement) and also in Latin America with MERCOSUR and other trade agreements. In the Asian countries, however, it is only an embryonic phenomenon, and this has increased the seriousness of their crises, for all these countries must find outlets outside Asia, thus leading to a depressive spiral within their own area. In contrast, the establishment of the Euro received unexpected support when the 1997 and 1998 financial crises occurred: it was seen that the currencies in the Euro basket remained stable, whereas the currencies outside it suffered notable changes in their exchange rates. It is in such spaces (Europe and North America) that supranational, but not necessarily world-level, institutions can try to discipline finance and organize competition so as to maximize its favourable effects for the area as a whole. In this respect, political integration can be more effective than the establishment of a mere free trade area, as is suggested by the differences between the paths followed by Europe and Southeast Asia in the 1990s. Likewise, the tensions registered in 1999 in MERCOSUR suggest that a free trade area should include coordination of monetary and exchange rate policies, which means giving up part of national sovereignty in the interest of joint decisions. A movement which has taken almost half a century in Europe (Boyer, 1998) cannot be carried out elsewhere within the time limits demanded by the present financial globalization. This is a serious difficulty, of a political and not just an economic and financial nature, which stands in 
the way of the establishment of regional integration areas (Frémeaux, 1998).

States always have the option of redefining their international linkages. Some governments may rightly consider that it is finance which has destabilized national forms of organization and brought on crises. While continuing to seek their place in an international division of labour which stimulates innovation and improves production methods and standards of living, countries can nevertheless more or less radically restrict the circulation of financial capital or at least impose precise rules on its entry. Such a movement would be more or less the opposite to the "Multinational Investment Agreement" (MIA) which is being negotiated under the auspices of the OECD but has been held up by strong opposition. The measures taken by Malaysia show that the internationalization process can suffer some setbacks as a result of major crises which shed doubts on the viability of the previous form of international linkages. If the financial crisis were to get worse, this type of strategy could begin to be copied

\section{VIII}

\section{Conclusions}

At the beginning of the 1990s it was fashionable to talk about "the end of history", on the grounds that the confrontation between the antagonistic social and political regimes of capitalism on the one side and communism on the other had come to an end. However, those who believed this had forgotten the extraordinary innovative capacity of capitalism and above all of finance. In the space of only a decade, internationalization and the predominance of a finance-based approach have changed the world and radically altered the situation of capitalism. The political agenda has been totally transformed, and the authorities now have a dual task: first, and above all, to "domesticate" finance and the market again and make them into means for ensuring the welfare of societies rather than as final objectives in themselves, and second, to renovate international commitments so that they will give rise to forms of growth that do not make exporting at all costs the basic by other countries, regardless of what the advocates of the superiority of total free trade may think, although on the other hand, what has happened between 1997 and 1999 gives no indication of an impending catastrophe like that announced by countries such as Malaysia, which have tried to free themselves from short-term capital movements.

Organizing a withdrawal into protectionism, even at the cost of a rebirth of nationalism (and not only in economic matters), would be the last option that some governments might be tempted to explore, if they had not been able to carry out any of the preceding strategies successfully. The example of the period between the wars shows that some events, if sufficiently dramatic, could bring this strategy up again as a possibility, even though an ex post facto analysis would show that it would lead to even greater evils than those caused by international finance at its worst. In the light of these problems, the political and economic disturbances observed since August 1998 give grounds for thinking that one of the first candidates for adopting such a strategy might be Russia. mainspring of each country's economic and social growth.

It is quite true that the buoyant growth of the United States, the resurgence of the Japanese economy and the establishment of the Euro have given grounds for renewed optimism and that many analysts think that the renewed economic dynamism will make it possible to avoid the return of the financial instability of the past without making any major reforms. Nevertheless, the imbalances that appeared in the 1990s are still with us and could surge up again if, for example, the United States economy were to go into a recession. That would indeed be the touchstone of true reality: the "New Economy" on the one hand and the viability of the present international configuration on the other.

For this reason, a genuine New Deal is and must continue to be high on the world agenda.

(Original: French) 


\section{Bibliography}

Aglietta, M. (1976): Régulation et crises du capitalisme: l'expérience des Etats-Unis, Paris, Calmann-Lévy.

- (1995): Macroéconomie financière, Paris, Collection Repères, La Découverte.

- (1998): La maîtrise du risque systémique international, Économie internationale, No. 76, Paris, La Documentation Française

Aglietta, M., A. Brender and V. Coudert (1990): Globalisation financière: l'aventure obligée, Paris, Economica.

Aglietta, M. and J. Cartelier (1998): Ordre monétaire des économies de marché, in M. Aglietta and A. Orléan (eds.), La monnaie souveraine, Paris, Éditions Odile Jacob.

Aglietta, M. and A. Orléan (eds.) (1998): La monnaie souveraine, Paris, Éditions Odile Jacob.

Amable, B., R. Barré and R. Boyer (1997): Les systèmes d'innovation à l'ère de la globalisation, Paris, Economica/Observatoire des Sciences et des Techniques (OST).

Artus, P. and M. Debonneuil (1999): Crises, recherches de rendement et comportements financiers, Conseil d'Analyse Economique, No. 18, Paris, La Documentation Française.

Berger, S. and R. Dore (eds.) (1996): National Diversity and Global Capitalism, New York, Cornell University Press.

BIS (Bank for International Settlements) (1998): Report of the Basle Committee on Banking Supervision, Basle.

Bowles, S. and R. Boyer (1995): Wages, aggregate demand and employment in an open economy: An empirical investigation, in G. A. Epstein and H. M. Gintis (eds.), Macroeconomic Policy after the Conservative Era. Studies in Investment, Savings and Finance, Cambridge, Massachusetts, Cambridge University Press.

Boyer, R. (1997): La globalizacion: mitos y realidades, in E. Gutiérrez Garza and J. M. Infante (coords.), El debate nacional. Tomo 1: México en el siglo XXI, Mexico City, Universidad Autónoma de Nuevo León/Diana.

(1998): An Essay on the Political and Institutional Deficits of the Euro. The Unanticipated Fallout of the European Monetary Union, Couverture Orange CEPREMAP, No. 9813, Paris, Centre for Prospective Studies on Mathematical Economics Applied to Planning, August.

(1999a): Le gouvernement de la zone Euro: Rapport pour le Commissariat Général du Plan, Paris, La Documentation Française.

- (1999b): The diversity and future of capitalism. A "regulationist analysis", in G. Hodgson and N.
Yokokawa (eds.), Capitalism in Evolution, London, Edward Elgar (forthcoming).

Boyer, R. and Y. Saillard (eds.) (1995): Théorie de la régulation: L'état des savoirs, Paris, La Découverte.

Brenner, R. (1998): The economics of global turbulence. A special report on the world economy, 1950-98, New Left Review, No. 229, London, New Left Limited.

Buiter, W. and A. Sibert (1999): A small contribution to the new international financial architecture, (summarized in The Economist, London, 1 May).

Business Week (1998): A new deal on global debt, New York, The McGraw-Hill Companies, 7 September.

Camdessus, M.(1998): Allocution devant le World Affairs Council, Washington, D.C., International Monetary Fund (IMF), 6 November.

CAE (Conseil d'Analyse Économique) (1999a): Réforme du système monétaire international: le point de vue de Fred Bergsten, Lettres du CAE, No. 1, Paris.

- (1999b): Architecture du système financier international, Lettres du CAE, No. 5, Paris

Contamin, R. and C. Lacu (1998): Origines et dynamiques de la crise asiatique, L’Année de la Régulation 1998, vol. 2, Paris, La Découverte.

Croff, D. (1999): Global supervision, financial stability and risk control: a banker's view, Quarterly Review, No. 29, Rome, Banca Nazionale del Lavoro, June.

Davanne, O. (1998): Instabilité du système financier international, Conseil d'Analyse Économique, No. 14, Paris, La Documentation Française.

Dornbush, R. A. (1998): The Japanese crisis and the bureaucrats, Far Eastern Economic Review, Hong Kong, 26 February.

Economie Internationale (1998): Les crises en Asie, No. 76, Paris, La Documentation Française.

Eliasson, G. (1984): Micro heterogeneity of firms and the stability of industrial growth, Journal of Economic Behavior and Organization, vol. 5, No. 3-4, Amsterdam, The Netherlands, North-Holland Publishing Company.

Epstein, G. (1996): International capital mobility and the scope for national economic management, in $\mathrm{R}$. Boyer and D. Drache (eds.), States Against Markets, London, Routledge.

Freeman, R. (1998): Le modèle économique américain à l'épreuve de la comparaison, Actes de la Recherche en Sciences Sociales, No. 124, Paris, Diffusion Le Seuil, September.

Frémeaux, P. (1998): Sortir du piège. La gauche face à la mondialisation, Paris, Syros.

Froud, J., C. Haslam, S. Johal, A. Leaver, J. Williams and K. Williams (1998): Accumulation based on in- 
equality: A Keynesian analysis of investment for shareholder value, Manchester University, July, mimeo.

Godement, F. (1999): The Downsizing of Asia, London, Routledge.

ul Haq, M., I. Kaul and I. Grunberg (eds.) (1996): The Tobin Tax. Coping with Financial Volatility, Oxford, U.K., Oxford University Press.

Helleiner, E. (1996): Post globalization: Is the financial liberalization trend likely to be reversed ?, in R. Boyer and D. Drache (eds.), States against Markets, London, Routledge.

Hochraich, D. (1999): L'Asie, du miracle à la crise, Paris, Complexe.

Hollingsworth, R. and R. Boyer (eds.) (1997): Contemporary Capitalism : The Embeddedness of Institutions, Cambridge, Massachusetts, Cambridge University Press.

IDB (Inter-American Development Bank) (1995): Overcoming volatility, Economic and Social Progress in Latin America. 1995 Report, Washington D.C., October.

-(1997): Latin America after a Decade of Reforms, Washington D.C., September.

IMF (International Monetary Fund) (1998a): Le Brésil et le FMI annoncent le succès de leurs négociations, IMF Bulletin, vol. 27, No. 21, Washington, D.C., 23 November.

(1998b): Report of the Managing Director to the Interim Committee on Strengthening the Architecture of the International Monetary System, Washington, D.C., 1 October, mimeo.

Japan Almanac 1998 (1998): Tokyo, Asahi Shimbun Publishing Company.

Japan Almanac 1999 (1999): Tokyo, Asahi Shimbun Publishing Company.

Kaldor, N. (1940): Spéculation et stabilité économique, Revue Française d'Économie, vol. 2, No. 3, Paris, Gauthier-Villars, May.

Keizai Koho Center (1998): Japan An International Comparison, Tokyo.

Keynes, J. (1935): The General Theory of Employment, Interest and Money.
Kindleberger, C. P. (1978): Manias, Panics, and Crashes: A History of Financial Crises, New York, Basic Books.

Lafay, G., M. Freudenberg, C. Herzog and D. Ünal-Kesenci (1999): Nations et mondialisation, Paris, Economica.

McKinnon, R. (1999): Wading in the yen trap, The Economist, London, 24-30 July.

OECD (Organization for Economic Cooperation and Development) (1998a): Perspectives Économiques, Paris, June.

(1998b): Financial Market Trends, No. 70, Paris, June.

Orléan, A. (1998): La monnaie autoréférentielle: réflexions sur les évolutions monétaires contemporaines, in M. Aglietta and A. Orléan (eds.), La monnaie souveraine, Paris, Éditions Odile Jacob.

- (1999): Le pouvoir de la finance, Paris, Éditions Odile Jacob.

Polanyi, K. (1946): The Great Transformation. Paris, Gallimard.

Rohatyn, F. (1999): Sortir de la crise financière, Risques, No. 37, Paris, LGDJ, January-March.

Sapir, J. (1996): Le Chaos Russe, Paris, La Découverte.

(1998): Le Krach Russe, Paris, La Découverte.

The Economist (1998): Financial indicators, London, 19-25 September.

- (1999a): Global finance: Time for a redesign?, London, 30 January-5 February.

(1999b): The New Economy: Work in progress, London, 24-30 July.

Tobin, J. (1978): A proposal for international monetary reform, Eastern Economic Journal, No. 4, July-October.

UNCTAD (United Nations Conference on Trade and Development) (1998): Trade and Development Report 1998, New York.

Williamson, M. and M. Mahar (1999): A survey of financial liberalization, Essays in International Finance, No. 211, Princeton, New Jersey, Princeton University.

World Bank (1993): The East Asian Miracle: Economic Growth and Public Policy, Washington, D.C.

(1999): Global Development Finance, World Bank, Washington D.C. 